\title{
The Influence of Free Transport in Rail Passenger Transport on the Elasticity of Demand of Rail Passenger Transport
}

\author{
Eva Brumerčíková, ${ }^{1, *}$, Bibiana Buková ${ }^{1}$, and Pavol Kondek ${ }^{1}$ \\ ${ }^{1}$ University of Žilina, Faculty of Operation and Economics of Transport and Communications \\ Department of Railway Transport, Univerzitná 1, 01026 Žilina, Slovakia
}

\begin{abstract}
The article focuses on the elasticity of the demand for transport services in rail passenger transport in the Slovak Republic after introducing free transport for students and retirees. The article studies the impact on income and cross elasticity, given that the fare for rail transport is regulated by the state and, therefore, there is no price elasticity. The article characterizes the volume of transport services in rail passenger transport and the impact of the introduction of free transport on the cross and income elasticity.
\end{abstract}

\section{Introduction}

The elasticity (flexibility) of demand reflects how the demand for a product changes when its price or the price of substitute goods changes or when revenue changes. The individual coefficients of elasticity measure changes in demand with respect to changing one of the factors, while the other conditions remain unchanged. Demand for rail passenger transport in the Slovak Republic declined and transport became an inferior product. In November 2014, Slovak Republic introduced free rail passenger transport for selected groups of passengers. The article summarizes the changes in elasticity after the introduction of the free rail passenger transport.

\section{Demand for transport services}

The necessary data for calculating the coefficients of all monitored types of elasticity is the volume of transport services in rail passenger transport in the Slovak Republic for the whole monitored period of 10 years. Demand for transport services is shown in Table 1 and is shown in millions pkm.

\footnotetext{
*Corresponding author: eva.brumercikova@,fpedas.uniza.sk
} 
Table 1. Demand for transport services. Source: [1]

\begin{tabular}{|l|c|c|c|c|c|c|c|c|c|c|}
\hline Year & 2006 & 2007 & 2008 & 2009 & 2010 & 2011 & 2012 & 2013 & 2014 & 2015 \\
\hline Demand & 48438 & 46984 & 48655 & 46597 & 46509 & 47453 & 44609 & 45946 & 49098 & 60292 \\
\hline Index & - & 0,96998 & 1,03557 & 0,9577 & 0,99811 & 1,0203 & 0,94007 & 1,02997 & 1,0686 & 1,22799 \\
\hline
\end{tabular}

The table 1, it is clear that Slovakia recorded the largest increase in passenger numbers in 2015, which influenced the introduction of free transport from 17th November 2014. On the contrary, the largest decline in using the rail transport was in 2012. Slovakia does not make significant fluctuations in the use of passenger rail transport except for 2014 and 2015 when introducing free passenger transport. The increase in demand between 2006 and 2015 is $24.47 \%$. The demand for transport services for the year 2016 has not been published yet.

\section{Income elasticity}

Income elasticity reflects how the demand for rail transport service changes if revenue is changed, i.e. if the real income increases, the demand should increase, too. In the case of rail transport, it is assumed that the increase in the income of the population will increase the number of cars and the demand for rail passenger transport will decrease [2, 3]. Calculation of income elasticity (equation 1):

$$
E_{p}=\frac{\frac{\Delta Q_{\check{Z} \check{D}}}{Q_{\check{Z} D}}}{\frac{\Delta I_{j}}{I_{j}}}
$$

where: $E_{p}$ - coefficient of income elasticity; $Q_{z ̌ D}$ - demand for the rail transport services; $I_{j}$ unit revenue (income per person).

According to the final value of elasticity we distinguish following results:

good result what happens

Normal: $\quad \mathbf{E}_{\mathbf{p}}>0 \quad$ With the increase in income, the amount of purchased goods is increasing.

Luxury: $\quad \mathbf{E}_{\mathbf{p}}>1 \quad$ The amount of purchased goods grows faster than the consumer's income.

Necessity: $\quad 0<\mathbf{E}_{\mathbf{p}}<1 \quad$ The amount of purchased goods is growing more slowly than the consumer's income.

Inferior: $\quad \mathbf{E}_{\mathbf{p}}<0$

With the growth of income, the demand for inferior goods declines and vice versa $[4,5]$.

In order to calculate the income elasticity coefficient, the average annual unit income in the Slovak Republic has to be analyzed, as shown in the following Table 2.

Table 2. Average income in Slovak Republic. Source: [1]

\begin{tabular}{|l|c|c|c|c|c|c|c|c|c|c|}
\hline Year & 2006 & 2007 & 2008 & 2009 & 2010 & 2011 & 2012 & 2013 & 2014 & 2015 \\
\hline Average wage & 8694 & 9469 & 9991 & 10334 & 10897 & 11218 & 11475 & 11716 & 11932 & 12305 \\
\hline Index & - & 1,08914 & 1,05513 & 1,03433 & 1,05448 & 1,02946 & 1,02291 & 1,021 & 1,01844 & 1,03126 \\
\hline
\end{tabular}


Based on Table no. 2 it is possible to compare the average annual income in the Slovak Republic. The table shows that the average income rises by $3.96 \%$ on average in 10 years. Between 2006 and 2015 the average income increased by $41 \%$.

Table 3. Income elasticity coefficients in the Slovak Republic. Source: authors

\begin{tabular}{|c|c|c|c|c|c|c|c|c|c|c|}
\hline Year & 2006 & 2007 & 2008 & 2009 & 2010 & 2011 & 2012 & 2013 & 2014 & 2015 \\
\hline $\begin{array}{c}\text { Income } \\
\text { elasticity }\end{array}$ & - & $-0,378$ & 0,657 & $-1,331$ & $-0,037$ & 0,695 & $-2,847$ & 1,415 & 3,546 & 6,125 \\
\hline
\end{tabular}

According to Table 3, it can be assumed that in 2007, 2009, 2010 and 2012, rail transport in Slovakia was considered an "inferior" good, as the income elasticity coefficient was negative which means that the demand for rail transport decreased with the growth of retirement income. In 2008 and 2011, rail transport can be assessed as a necessity good, so the number of passengers transported is increasing more slowly than the consumer's income. This can be noticed, for example, when comparing the years 2008 and 2007, when average income grew by $5.5 \%$, while the number of passengers transported grew only by $3.5 \%$.

We can denote the rail transport in Slovakia between 2013 and 2015 as a luxury good, when under the influence of the introduction of free transport there was a significant difference between the increase in average income and the increase in the number of passengers transported. In order to be able to state, based on the above mentioned facts, that rail transport is an "inferior" good, Table no. 1 shows the Engel curve for inferior goods [6, 7]. The graph shows that rail transport could be considered a necessity good, as the Engel curve is a concave. In the case of an average income greater than $11500 \mathrm{EUR}$, rail transport becomes an "exclusive" good when the demand is rising sharply.

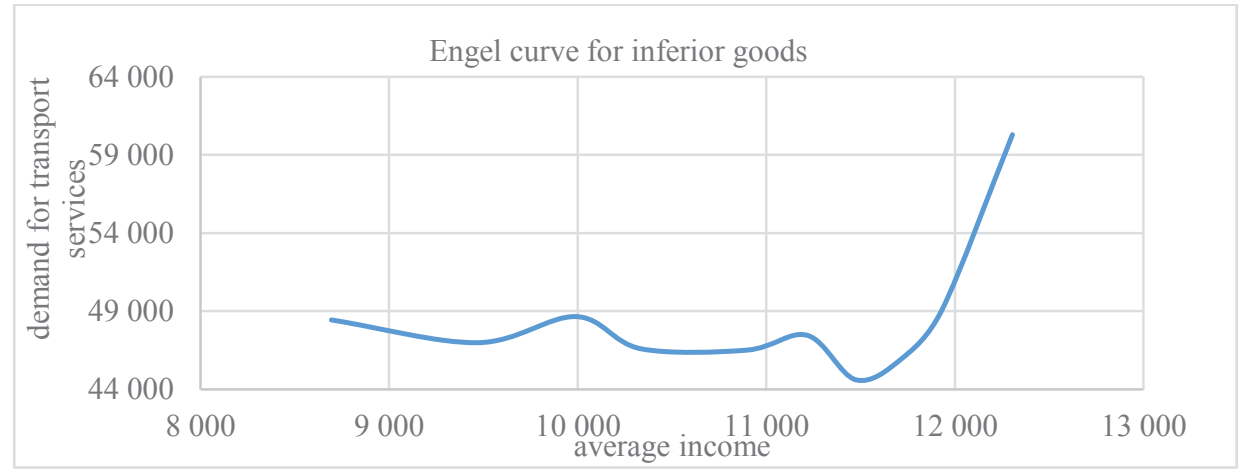

Fig. 1 Engel curve for inferior goods. Source: authors

\section{Cross elasticity}

Cross elasticity expresses how demand changes if the price of another type of transport changes, provided that the cost of the rail transport service remains unchanged. Cross elasticity gains values:

- $\mathrm{E}_{\mathrm{k}}>0$ - substitution effect, i.e. in the case of a reduction in the price of another type of transport, the demand for rail transport services is reduced, provided that the price of the rail transport service does not change. In this case, the consumer replaces the more expensive good with a cheaper one, hence abandoning the use of rail transport. The higher the cross elasticity of the goods $\mathrm{X}$ and $\mathrm{Y}$, the more they are substitutable. 
- $\mathrm{E}_{\mathrm{k}}<0$ - a complementary effect, i.e. the service of another type of transport is complementary to the rail transport service. In such a case, the reduction in the prices of rail transport services will cause an increase in demand for rail transport as well as in its supplementary services.

- $\mathrm{E}_{\mathrm{k}}=0$ - cross elasticity does not apply $[8,9]$.

Cross-elasticity can be expressed as follows:

$$
E_{k}=\frac{\frac{\Delta Q_{\check{Z} D}}{Q_{\check{Z} D}}}{\frac{\Delta P_{j}}{P_{j}}}
$$

where: $\mathrm{E}_{\mathrm{k}}$ - coefficient of cross elasticity; $\mathrm{Pj}$ - price of the service of another type of transport.

The demand for rail passenger services is also specific for cross elasticity measurements when compared to individual car traffic. In addition, if the price of individual car transport increases, there is no increase in demand for rail passenger transport [10-12].

Table no. 4 displays the analysis of fuel prices, namely oil fuel, in the Slovak Republic for a time period of 10 years. The given results are the annual average prices of fuel and they are stated in the purchase price.

Table 4. Oil fuel price per 11 in $€$. Source: [1]

\begin{tabular}{|l|c|c|c|c|c|c|c|c|c|c|}
\hline Year & 2006 & 2007 & 2008 & 2009 & 2010 & 2011 & 2012 & 2013 & 2014 & 2015 \\
\hline Average price of diesel & 1,318 & 1,245 & 1,383 & 1,096 & 1,114 & 1,34 & 1,441 & 1,39 & 1,334 & 1,135 \\
\hline Index & - & 0,9446 & 1,1108 & 0,7925 & 1,0164 & 1,2029 & 1,0754 & 0,9646 & 0,9597 & 0,8508 \\
\hline
\end{tabular}

Table 4 shows that the price of fuel, in particular oil fuel, has varied depending on excise duty applied to oil fuel. The lowest decrease can be seen between 2014 and 2015, when the price of oil fell most in the studied period.

The following table no. 5 shows the cross elasticity coefficients for the studied period in the SR.

Table 5. Cross elasticity coefficients. Source: authors

\begin{tabular}{|c|c|c|c|c|c|c|c|c|c|c|}
\hline Year & 2006 & 2007 & 2008 & 2009 & 2010 & 2011 & 2012 & 2013 & 2014 & 2015 \\
\hline Cross elasticity & - & 0,528 & 0,344 & 0,169 & $-0,117$ & 0,118 & $-0,91$ & $-0,793$ & $-1,529$ & $-1,059$ \\
\hline
\end{tabular}

Between 2007 and 2009, substitution effect prevailed in Slovakia, which means that when reducing the price of oil fuel, passengers used rail passenger transport less and used other alternatives instead. For example, the number of passengers decreased by $3 \%$ in 2007 , and oil fuel prices, which were developing in the same way, decreased by $5.5 \%$. The change occurred in 2012, 2013, 2014 and 2015 when, for example, oil fuel prices decreased by almost $15 \%$ in 2015 , causing that the number of transported passengers grew by almost $23 \%$. Thus, the monitored goods are already considered complementary during this period because it is no longer possible to reduce oil fuel prices so much that they can compete with free rail passenger transport $[13,14]$.

\section{Conclusion}

Two types of elasticity were observed in the elasticity of demand for transport services in rail passenger transport. The first observed parameter was income elasticity, where the impact of changes in the average annual income of the country's inhabitants on the demand for transport by rail was determined. It was discovered that in the past rail transport in the 
Slovak Republic was considered to be inferior, later a necessity good, however in the last observed time period it has the characteristics of a luxury good when under the influence of the introduction of free transport there has been a significant difference between the increase in average income and the increase in the number of passengers transported.

The second parameter was cross elasticity, where the effect of the change in the price of oil fuel on the performance of rail passenger transport was determined. In the first observed years in the Slovak Republic, the substitution effect prevailed when oil fuel prices and the number of persons transported in rail transport were developing in the same way. The change occurred only when the free rail passenger transport was introduced, where the reduction in the price of oil fuel did not affect the reduction of the volume of transport by rail.

The paper is supported by the VEGA Agency by the Project 1/0095/16 "Assessment of the quality of connections on the transport network as a tool to enhance the competitiveness of public passenger transport system", that is solved at Faculty of Operations and Economics of Transport and Communication, University of Zilina.

This paper is supported by the research project "From horse-drawn railway to intermodal transport" within Visegrad Fund.

\section{References}

1. Eurostat, statistical data, Available online: www.ec.europa.eu/eurostat/ (2017)

2. A. Dolinayova, E. Nedeliakova, E. Brumercikova, Economy of Railway Transport: Monography, (University of Zilina, Slovakia, 2016)

3. L. Cerna, V. Zitricky, J. Ponicky, MME 2016, 126-131 (2016)

4. J. Danis, A. Dolinayova, J. Camaj, AER - Advances in Engineering Research 62, 187190 (2016)

5. L. Cerna, V. Zitricky, J. Danis, Open Engineering 7, 6-13 (2017), DOI: 10.1515/eng2017-0002

6. J. Masek, M. Kendra, Regulated and Unregulated Competition on Rails, 117-129 (2013)

7. Z. Krzysiak, G. Bartnik, W. Samociuk, J. Zarajczyk, K. Plizga, B. Rachwal, S. Wierzbicki, L. Krzywonos, F. Brumercik, Przemysl Chemiczny 96, 279-282 (2017)

8. L. Jedlinsky, J. Caban, L. Krzywonos, S. Wierzbicki, F. Brumercik, Journal of Vibroengineering 17, 175-187 (2015)

9. J. Cejka, L. Bartuska, L. Turinska, Open Engineering 7, 55-59 (2017), DOI: 10.1515/eng-2017-0010

10. J. Lizbetin, O. Stopka, Open Engineering 6, 441-445 (2016), DOI: 10.1515/eng-20160066

11. M. Yarmen, S. Sumaedi, S, Transport Problems 11, 99-111 (2016)

12. J. Lalinská, J. Gašparík, D. Šipuš, LOGI - Scientific Journal on Transport and Logistics 8, 1, 74-81 (2017), DOI: 10.1515/logi-2017-0009.

13. P. Stoyanov, P. Gagova, Transport Problems 7, 37-41 (2012)

14. M. Bak, P. Borkowski, B. Pawlowska, Transport Problems 7, 27-36 (2012) 